\title{
RESPONS PERTUMBUHAN DAN PRODUKSI BEBERAPA VARIETAS PADI GOGO (Oriza sativa L.) DENGAN KETEBALAN TANAH MINERAL PADA LAHAN GAMBUT
}

\author{
Growth and Production Response of Upland Rice (Oryza sativa L.) Varieties by Thickness of \\ Mineral Soil at Peat Soil
}

Maslaita*, Abdul Rauf dan Edison Purba

Program Studi Master Agroekoteknologi, Fakultas Pertanian, USU. Medan 20155

*Coresponding author: maslaita@yahoo.co.id

\begin{abstract}
A large area of feat soil as available across Aceh Singkil province of Aceh. The possibility of the area for upland rice farming is necessary tube evaluated. This study aim to evaluate the growth and yield of upland rice varieties on peat soil with different thickness of soil. The research used randomized block design with 2 (two) factors. The first factor was rice varieties (V) were consist of (1) Local variety (Siliam varieties), (2) Situ Bagendit varieties, (3) Situ Patenggang varieties and (4) Batutegi varieties. Where as the second factor thickness of mineral soil applied on peat wich consist of $5 \mathrm{~cm}, 10 \mathrm{~cm}, 15 \mathrm{~cm}, 20 \mathrm{~cm}$ and no mineral soil as a control. The results indicated that varieties of upland rice showed significant effect on the growth and production variable such as plant height 4, 6, 8 and 10 weeks after planting, where Situ Bagendit variety was the highest among the varieties. Similarly number of tillers 4, 6, 8 and 10 weeks after planting, the highest number of tillers was found on Situ Bagendit variety, while for highest number of grain per panicle was in Batutegi varieties. The thickness of mineral soil applicated on peat soil indicated significant effect on the growth and production variables such as plant height 4 weeks after planting. The highest yield of upland rice was fond on Situ Bagendit variety followed by Batutegi variety, Situ Patenggang variety and local variety (Siliam variety).
\end{abstract}

Key words : upland rice varieties, thickness of mineral soil, peat soil, rice.

\begin{abstract}
ABSTRAK
Masih tersedia lahan gambut yang luas di Aceh Singkil provinsi Aceh. Pengembagannya untuk pertanian padi gogo perlu dilakukan evaluasi. Penelitian ini bertujuan untuk mengevaluasi pertumbuhan dan produksi beberapa varietas padi gogo dengan ketebalan tanah mineral pada lahan gambut. Penelitian ini dilakukan di daerah lahan gambut disekitar Singkil, Aceh Singkil, Provinsi Aceh. Kemungkinan pada daerah lahan gambut perlu untuk di evaluasi. Penelitian ini menggunakan Rancangan Acak Kelompok (RAK) dengan 2 (dua) faktor. Varietas padi (V) terdiri dari (1) varietas lokal, (2) varietas Situ Bagendit, (3) varietas Situ Patenggang, (4) varietas Batutegi. Dimana ketebalan tanah mineral yang diaplikasikan diatas tanah gambut yaitu $5 \mathrm{~cm}, 10 \mathrm{~cm}, 15 \mathrm{~cm}, 20 \mathrm{~cm}$, tanpa tanah mineral $/ 0 \mathrm{~cm}$ sebagai kontrol. Hasil penelitian ini menunjukkan bahwa perlakuan varietas padi gogo memperlihatkan pengaruh nyata pada peubah pertumbuhan dan produksi seperti tinggi tanaman 4, 6, 8 dan 10 minggu setelah tanam (MST), dimana varietas Situ Bagendit merupakan varietas yang tertinggi diantara varietas lainnya, hal yang sama pada pengamatan jumlah anakan pada umur 4, 6, 8 dan $10 \mathrm{MST}$, jumlah anakan produktif ditemukan pada varietas Situ Bagendit. Sedangkan jumlah gabah per malai tertinggi terdapat pada varietas Batutegi. Pemberian amelioran tanah mineral yang diaplikasikan diatas tanah gambut memperlihatkan pengaruh nyata pada peubah pertumbuhan dan produksi seperti tinggi tanaman 4 minggu setelah
\end{abstract}


tanam (MST). Hasil yang tertinggi pada lahan gambut diperoleh pada varietas Situ Bagendit diikuti oleh varietas Batutegi, varietas Situ Patenggang dan varietas Lokal (varietas Siliam).

Kata kunci : varietas padi gogo, ketebalan tanah mineral, gambut, padi.

\section{PENDAHULUAN}

Tanaman padi merupakan tanaman penting di Asia terutama di Indonesia. Padi menghasilkan beras menjadi makanan pokok menyediakan $35-80 \%$ dari total kalori yang dibutuhkan manusia (IRRI 1997). Lebih dari dua milyar penduduk dibumi mengkonsumsi beras, $90 \%$ beras dunia ditanam dan dikonsumsi di Asia. Diprediksikan 1,4 milyar manusia bertambah sebagai pengkonsumsi baru beras sampai tahun 2025 (Damanik, 2002).

Ketersediaan beras untuk memenuhi kebutuhan penduduk Indonesia merupakan masalah. Dalam tahun 2010 produksi padi sebesar 66,47 juta ton atau dalam bentuk beras sebesar 41,88 juta ton, mengalami penurunan pada tahun 2011 sebesar 65,38 juta ton atau beras sebesar 41,26 juta ton, tahun 2012 mengalami peningkatan menjadi 68,77 juta ton atau dalam bentuk beras sebesar 43,33 juta ton dan pada tahun 2013 diperkirakan mencapai 68,99 juta ton atau dalam bentuk beras sebesar 43,46 juta ton. Permasalahan ini timbul disebabkan oleh beberapa faktor yaitu laju pertumbuhan penduduk Indonesia yang terus meningkat yakni sebesar $2 \%$ per tahun, akibat alih fungsi lahan menjadi lahan nonpertanian, timbulnya masalah baru seperti musim kering yang panjang, masalah banjir dan keterlambatan musim tanam. Untuk mengatasi kebutuhan pangan ini maka, diperlukan terobosanterosan baru yang signifikan sehingga mampu mengurangi laju impor Indonesia (Adiratma, 2005; BPS 2013).

Padi gogo adalah salah satu jenis padi yang ditanam di daerah tegalan atau di tanah kering secara menetap oleh beberapa petani. Padi gogo tidaklah membutuhkan air yang banyak dalam penanamannya. Pada umumnya ditanam di daerah tanah kering sehingga banyak kita jumpai di daerah yang berbukitbukit (Priyastomo et al. 2006).
Salah satu faktor menyebabkan rendahnya produksi padi gogo adalah kurangnya galur-galur harapan yang adaptif yaitu yang memiliki kualitas beras baik, potensi hasil sedang, tahan terhadap hama dan penyakit, serta toleran terhadap tekanan mineral. Rata-rata produksi padi gogo secara nasional baru mencapai 2,58 ton/ha masih rendah apabila dibandingkan dengan padi sawah yang dapat mencapai rata-rata produksi sebesar 5,68 ton/ha (Balai Penelitian Tanaman Padi 2005).

Terdesaknya fungsi pemanfaatan lahan pertanian di Pulau Jawa akibat laju pembagunan menyebabkan penyediaan pangan untuk masa mendatang tidak dapat lagi bertumpu di Pulau Jawa yang selama ini memasok 60\% kebutuhan pangan nasional. Langkah strategis yang perlu dilakukan adalah memberikan perhatian yang lebih besar terhadap pemanfaatan lahan-lahan marginal yang ada diluar Pulau Jawa dan mengendalikan secara ketat laju alih fungsi lahan pertanian di Pulau Jawa (Supriyo dan Maftua'ah, 2009).

Lapulisa dan Siddieq (1998), usaha mempertahankan swasembada pangan dilakukan oleh pemerintah melalui perluasan areal (ekstensifikasi) yang dihadapkan dengan semakin berkurangnya lahan produktif. Proyeksi kebutuhan lahan pertanian sampai 2020 akan mencapai 70,88 juta ha dibandingkan dengan kebutuhan lahan pada tahun 1990 yaitu seluas 37,0 juta ha, diantaranya adalah dengan memanfaatkan lahan gambut. Zuraida (2013), menambahkan bahwa permintaan lahan yang sangat besar dimasa mendatang akan menyebabkan meningkatnya permintaan lahan marginal termasuk lahan gambut.

Melihat kenyataan di atas, maka perlu dicarikan cara yang lebih mudah diterima dan mampu diaplikasikan petani. Salah satu caranya yaitu memformulasikan bahan-bahan yang lebih efektif dalam menetralkan 
fitotoksik di samping meningkatkan $\mathrm{pH}$ (Setiawati, 2011).

Beberapa penelitian untuk menghasilkan teknologi yang dapat meningkatkan kesuburan tanah tanpa menggunakan pupuk kimia buatan telah banyak dilakukan. Salah satu teknologi yang saat ini dikembangkan adalah pemanfaatan bahan-bahan perbaikan tanah (amelioran) seperti kapur dolomite, tanah mineral (Nurhayati, 2013).

Tanah mineral dapat digunakan sebagai bahan amelioran karena mengandung unsur perekat (liat) dan memiliki unsur-unsur hara yang lebih lengkap diantaranya $\mathrm{Al}, \mathrm{Fe}$ dan Silikat $\left(\mathrm{SiO}_{2}\right)$. Penambahan bahan mineral ke dalam tanah gambut akan memperbaiki sifat kimia dan fisik tanah gambut, terutama tekstur tanahnya. Gambut yang biasanya terlalu remah akan meningkat daya kohesinya, menurun daya ikatnya terhadap air dan meningkat daya dukungnya (Neliyati, 2005).

\section{BAHAN DAN METODE}

Penelitian ini dilaksanakan dilahan Unit Pelaksana Teknis Badan Balai Penyuluh Pertanian (UPTB BPP) Desa Ujung Bawang Kecamatan Singkil Kabupaten Aceh Singkil. Waktu pelelitian dilakukan selama \pm 4 bulan mulai April sampai Juli 2015. Penelitian menggunakan Rancangan Acak Kelompok (RAK) dengan 2 (dua) faktor dan 4 (empat) ulangan. Faktor pertama varietas (V) dengan 4 (empat) taraf yaitu varietas lokal (varietas Siliam), varietas Situ Bagendit, varietas Situ Patenggang, varietas Batutegi. Faktor kedua ketebalan tanah mineral yang diaplikasikan diatas tanah gambut dengan 5 (lima) taraf yaitu tanpa tanah mineral/0 $\mathrm{cm}$ sebagai kontrol (100\% gambut), $5 \mathrm{~cm}, 10 \mathrm{~cm}, 15 \mathrm{~cm}$, $20 \mathrm{~cm}$.

\section{Pengembilan Contoh Tanah.}

Pengambilan contoh tanah yang digunakan diambil secara komposit. Untuk sampel tanah mineral, tanah dibersihkan dari sampah dan akar-akar kayu dengan menggunakan ayakan berdiameter 2 mesh.
Selanjutnya tanah diaduk merata, tanah yang telah tercampur diambil sampel tanahnya secara komposit. Kedua sampel tanah di atas selanjutnya dikering anginkan. Dimasukkan kedalam kantong plastik yang diberi label per perlakuan selanjutnya dibawa ke laboratorium.

\section{Persiapan Lahan}

Lahan gambut yang akan dijadikan sebagai lahan penelitian dibersihkan dari rerumputan dan sampah-sampah. Lahan yang telah bersih selanjutnya dibuat bedengan dengan ukuran $160 \mathrm{~cm}$ x $160 \mathrm{~cm}$ dengan jarak antar bedengan dalam baris $30 \mathrm{~cm}$ dan jarak bedengan atar blok/ulangan $100 \mathrm{~cm}$.

\section{Persiapan Tanah Mineral}

Tanah mineral yang digunakan jenis Ultisol atau sering disebut dengan podsolik merah kuning (PMK) diambil dari Kecamatan Gunung Meriah Kabupaten Aceh Singkil. Sebelum diaplikasikan tanah dibersihkan dari sampah dan akar-akar kayu dengan menggunakan ayakan berdiameter 2 mesh dan diaduk merata. Tanah yang telah merata dan bersih diaplikasikan sesuai perlakuan 2 hari sebelum tanam.

\section{Persiapan Benih}

Benih varietas padi gogo yang digunakan dalam penelitian ini terlebih dahulu direndam dalam air. Perendaman dilakukan selama 12 jam, dimaksudkan untuk mempermudah perkecambahan benih setelah penanaman di plot-plot penelitian. Benih yang telah selesai direndam kemudian dikeringkan, setelah itu dilakukan perlakuan benih dengan fungisida Beam $75 \mathrm{Wp}$ dan insektisida Furadan 3G.

\section{Penanaman}

Benih padi ditanam 2 benih pada setiap lobang tanam dengan jarak tanam $20 \mathrm{~cm}$ x 20 $\mathrm{cm}$. Penanaman dilakukan dengan cara tugal pada kedalaman $3 \mathrm{~cm}$. Setelah padi berumur 14 hari setelah tanam (HST) dilakukan penjarangan. 


\section{Penyiangan}

Penyiangan gulma dilakukan secara manual dengan cara mencabut langsung gulma dengan mengguakan tangan. Didaerah yang pertumbuhan gulma padat penyingan dilakukan secara manual dengan menggunakan tangan.

\section{Pengendalian hama dan penyakit}

Dilakukan penyemprotan dengan menggunakan insektisida dengan bahan aktif deltamethrin $25 \mathrm{cc} / \mathrm{l}$ dan fungisida dengan bahan aktif mancozeb $80 \%$. Pengendalian hama dan penyakit ini dilakukan dengan menggunakan handspayer.

\section{Pemanenan}

Pemanenan gabah dilakukan pada saat daun tanaman padi sudah mulai menguning semuanya atau daun kuning sudah mencapai 90\% hanya daun bendera saja yang masih terlihat berwarna hijau. Kondisi ini diperkirakan 30-35 hari masa berbunga atau saat tanaman berumur antara 100-110 hari.

\section{Peubah Amatan: \\ Tinggi tanaman}

Pengukuran tinggi tanaman dilakukan saat tanaman berumur 4, 6, 8 dan 10 minggu setelah tanam (MST). Sampel tanaman yang diamati 6 rumpun tanaman untuk setiap plot. Pada setiap sampel tanaman dibuat patok tanda sampel dari bambu. Pengukuran dimulai dari pangkal rumpun sampai ujung daun terpanjang dengan menggunakan meteran.

\section{Jumlah anakan per rumpun.}

Pengamatan jumlah anakan dihitung saat tanaman berumur 4, 6, 8 dan 10 MST. Jumlah anakan dihitung per rumpun tanaman sampel yang telah ditetapkan pada setiap plot.

\section{Jumlah anakan produktif.}

Jumlah anakan produktif dihitung saat panen, yang dihitung hanya anakan yang memiliki malai. Jumlah anakan dihitung per rumpun dari tanaman sampel yang telah ditetapkan pada setiap plot.

\section{Jumlah gabah per malai}

Jumlah gabah permalai dihitung dengan mengambil semua gabah seluruh malai tanaman sampel kemudian dirata-ratakan. Penghitungan dilakukan pada saat panen.

\section{HASIL DAN PEMBAHASAN}

\section{Pengaruh pertumbuhan dan produksi beberapa varietas padi gogo (Oriza sativa L.)}

Varietas padi gogo berpengaruh nyata terhadap pertumbuhan seperti tinggi tanaman 4, 6, 8 dan 10 MST dan produksi seperti jumlah anakan pada umur $4,6,8$ dan 10 MST, jumlah anakan produktif, jumlah gabah per malai.

Perlakuan varietas padi gogo memperlihatkan pengaruh nyata pada peubah tinggi tanaman 4, 6, 8 dan 10 MST. Perlakuan varietas Lokal Siliam memberikan pengaruh nyata lebih baik meningkatkan tinggi tanaman pada setiap umur amatan dibandingkan dengan varietas Situ Bagendit, varietas Situ Patenggang dan varietas Batutegi. Perlakuan varietas Lokal pada tanaman padi gogo membantu meningkatkan tinggi tanaman 4, 6, 8 dan 10 MST. Hal ini disebabkan karena varietas Lokal merupakan salah satu varietas unggul padi gogo yang sudah dilakukan introduksi dari luar negeri dan juga program pemuliaan sehingga dapat lebih unggul dibandingkan dengan varietas lainnya. Selain itu, lamanya fase vegetatif yang dimulai saat berkecambah sampai gabah matang untuk setiap varietas berbeda-beda sehingga menyebabkan terjadinya perbedaan tinggi tanaman hingga perbedaan umur panen. Balai Penelitian Tanaman Padi (2005), menyatakan bahwa cukup banyak varietas padi gogo yang telah dikenal petani. Sejak tahun 1960-2002, Badan Litbang Pertanian telah berhasil melepas 30 varietas unggul padi gogo, baik hasil pemutihan varietas Lokal, introduksi dari luar negeri maupun dari program pemuliaan. Balai Penelitian Tanaman Padi (2007), menyatakan bahwa lama fase vegetatif tidak sama untuk setiap varietas 
sehigga menyebabkan terjadinya perbedaan umur panen, sedangkan fase generatif dan pematangan gabah pada umumnya sama setiap varietas.

Perlakuan varietas padi gogo memperlihatkan pengaruh nyata terhadap peubah jumlah anakan 4, 6, 8 dan 10 MST dan jumlah anakan produktif. Perlakuan varietas Situ Bagendit memberikan pengaruh nyata lebih baik memperbanyak jumlah anakan pada setiap umur amatan dan jumlah anakan produktif, dibandingkan dengan varietas Lokal, varietas Situ Patenggang dan varietas Batutegi. Perlakuan varietas Situ Bagendit pada tanaman padi gogo memperbanyak jumlah anakan dan jumlah anakan produktif. Hal ini disebabkan karena lamanya fase vegetatif tidak sama untuk setiap varietas padi gogo sehigga menyebabkan terjadinya perbedaan menunjukkan pengaruh yang berbeda pada jumlah anakan. Dimana pola pertumbuhan

\section{Pertumbuhan dan produksi padi gogo (Oriza sativa L.) pada ketebalan tanah mineral berbeda}

Pemberian amelioran tanah mineral yang diaplikasikan diatas tanah gambut memperlihatkan pengaruh nyata pada peubah pertumbuhan dan produksi seperti tinggi tanaman 4 MST (Tabel).

Demikian juga pemberian amelioran tanah mineral memperlihatkan pengaruh nyata pada peubah tinggi tanaman 4 MST (Tabel). Ketebalan tanah mineral $10 \mathrm{~cm}\left(\mathrm{~T}_{2}\right.$ yang diaplikasikan di atas tanah gambut menghasilkan tinggi tanaman tertinggi pada umur 4 MST dibandingkan dengan tanpa tanah mineral $\left(\mathrm{T}_{0}\right)$ atau dengan tanah mineral ketebalan $5 \mathrm{~cm}\left(\mathrm{~T}_{1}\right), 15 \mathrm{~cm}\left(\mathrm{~T}_{3}\right)$ dan $20 \mathrm{~cm}$ $\left(\mathrm{T}_{4}\right)$. Ketebalan tanah mineral membantu meningkatkan tinggi tanaman 4 MST. Berdasarkan hasil analisis yang dilakukan PT. Nusa Pusaka Kencana Analitycal dan laboratory terhadap sampel tanah sebelum dan setelah penelitian pada tingkat ketebalan tanah mineral yang diperoleh hasil bahwa ketebalan tanah mineral pada tanah gambut tanaman padi ada 3 fase yaitu fase generatif, vegetatif dan fase pematangan gabah. Hal senada dikemukakan oleh Manurung dan Ismunadji (1988), menyatakan bahwa fase generatif ditandai dengan pembentukan anakan yang aktif, bertambah tingginya tanaman dan daun tumbuh secara teratur.

Perlakuan varietas padi gogo memperlihatkan pengaruh nyata pada peubah jumlah gabah per malai, jumlah gabah berisi per malai dan jumlah gabah hampa per malai. Perlakuan varietas Batutegi memberikan pengaruh nyata lebih baik meningkatkan jumlah gabah per malai, jumlah gabah berisi per malai dan jumlah gabah hampa per malai dibandingkan dengan varietas Lokal, varietas Situ Bagendit dan varietas Situ Patenggang. Manurung dan Ismunadji (1988), menyatakan bahwa lama fase reproduktif dan pematangan gabah dipengaruhi oleh faktor genetik yaitu masing-masing 30 hari.

meningkatkan $\mathrm{K}, \mathrm{Na}, \mathrm{Ca}, \mathrm{Mg}$, dan $\mathrm{pH}_{2} \mathrm{O}$. Hasil analisis tanah setelah penelitian meningkatkan kandungan $\mathrm{N}, \mathrm{C}, \mathrm{Ca}, \mathrm{Mg}, \mathrm{pH}$ $\left(\mathrm{H}_{2} \mathrm{O}\right)$, dimana kandungan $\mathrm{N}$ sebelum penelitian pada tanah gambut $1,92 \%$ dan setelah penelitian meningkat menjadi $2,00 \%$. Kandungan $\mathrm{C}$ sebelum penelitian pada tanah gambut adalah $45,45 \%$ meningkat menjadi $49,35 \%$.

Kandungan Ca sebelum penelitian pada tanah gambut adalah 7,19 meningkat menjadi 9,06 sesudah penelitian. Kandungan $\mathrm{Mg}$ pada tanah gambut sebelum penelitian adalah 2,97 $\%$ meningkat menjadi $3,12 \%$ sesudah penelitian. $\mathrm{pH}\left(\mathrm{H}_{2} \mathrm{O}\right)$ tanah gambut sebelum penelitian adalah 3,73 meningkat menjadi 4,01. Hasil penelitian Nurhayati (2013), menunjukkan bahwa perlakuan amelioran berpengaruh sangat nyata terhadap peubah peningkatan tinggi tanaman umur 4 minggu setelah tanam. Hal senada dikemukakan oleh Zuraida (2013), yang menyatakan bahwa pemberian amelioran pada tanah gambut sangat nyata meningkatkan $\mathrm{pH} \mathrm{H}_{2} \mathrm{O}, \mathrm{K}$-dd $\mathrm{Na}$-dd, Ca-dd, Mg-dd dan kejenuhan basa. 
Tabel Rata-Rata Tinggi Tanaman, Jumlah Anakan Per rumpun, Jumlah Anakan Produktif dan Jumlah Gabah per Malai Berbagai Varietas Padi Gogo Pada Ketebalan Tanah Mieral Pada Lahan

\begin{tabular}{|c|c|c|c|c|c|c|c|c|c|c|}
\hline \multirow[b]{2}{*}{ Perlakuan } & \multicolumn{4}{|c|}{ Tinggi Tanaman } & \multicolumn{4}{|c|}{ Jumlah Anakan Per rumpun } & \multirow{2}{*}{$\begin{array}{c}\text { Jumlah } \\
\text { Anakan } \\
\text { Produktif }\end{array}$} & \multirow{2}{*}{$\begin{array}{c}\text { Jumlah } \\
\text { Gabah } \\
\text { Permalai }\end{array}$} \\
\hline & 4 MST & 6 MST & 8 MST & $10 \mathrm{MST}$ & $\begin{array}{c}4 \\
\text { MST } \\
\end{array}$ & $\begin{array}{c}6 \\
\text { MST } \\
\end{array}$ & $\begin{array}{c}8 \\
\text { MST } \\
\end{array}$ & $\begin{array}{c}10 \\
\text { MST } \\
\end{array}$ & & \\
\hline \multicolumn{11}{|l|}{ Varietas } \\
\hline $\mathrm{V}_{1}$ (Lokal) & $43,33 \mathrm{a}$ & $64,19 \mathrm{a}$ & 85,16 a & 96,46 a & $1,70 \mathrm{~b}$ & $4,26 \mathrm{~b}$ & $5,23 \mathrm{~b}$ & $5,37 \mathrm{~b}$ & $2,55 \mathrm{c}$ & $181,62 \mathrm{~b}$ \\
\hline $\begin{array}{l}\mathrm{V}_{2} \text { (Situ } \\
\text { Bagendit) }\end{array}$ & $33,00 \mathrm{c}$ & $50,71 \mathrm{c}$ & $60,72 \mathrm{c}$ & $69,97 \mathrm{c}$ & $2,80 \mathrm{a}$ & $7,87 \mathrm{a}$ & $10,08 \mathrm{a}$ & $10,48 \mathrm{a}$ & $6,82 \mathrm{a}$ & $119,01 \mathrm{c}$ \\
\hline $\begin{array}{l}\mathrm{V}_{3} \text { (Situ } \\
\text { Patenggang) }\end{array}$ & $36,13 \mathrm{bc}$ & $57,06 \mathrm{~b}$ & $71,52 \mathrm{~b}$ & $87,61 \mathrm{~b}$ & $2,42 \mathrm{a}$ & $4,74 \mathrm{~b}$ & $5,40 \mathrm{~b}$ & $5,54 \mathrm{~b}$ & $4,02 \mathrm{~b}$ & $164,29 \mathrm{~b}$ \\
\hline $\mathrm{V}_{4}$ (Batutegi) & $38,01 \mathrm{~b}$ & $57,09 \mathrm{~b}$ & 79,37 a & $91,90 \mathrm{ab}$ & $1,66 \mathrm{~b}$ & $2,61 \mathrm{c}$ & $3,28 \mathrm{c}$ & $3,43 \mathrm{c}$ & $2,22 \mathrm{c}$ & $313,72 \mathrm{a}$ \\
\hline \multicolumn{11}{|c|}{ Ketebalan Tanah Mineral (T) } \\
\hline $\mathrm{T}_{0}(0 \mathrm{~cm})$ & $34,12 \mathrm{~b}$ & 55,29 & 73,53 & 85,73 & 1,80 & 4,41 & 5,91 & 6,17 & 3,73 & 200,02 \\
\hline $\mathrm{T} 1(5 \mathrm{~cm})$ & $37,99 \mathrm{a}$ & 56,59 & 73,97 & 88,49 & 2,30 & 5,04 & 6,29 & 6,67 & 4,11 & 199,39 \\
\hline $\mathrm{T}_{2}(10 \mathrm{~cm})$ & $39,51 \mathrm{a}$ & 58,30 & 74,68 & 86,75 & 2,52 & 5,67 & 6,59 & 6,76 & 3,98 & 194,54 \\
\hline $\mathrm{T}_{3}(15 \mathrm{~cm})$ & 38,11 a & 57,19 & 74,72 & 87,39 & 2,00 & 4,25 & 5,13 & 5,19 & 3,42 & 199,96 \\
\hline $\mathrm{T}_{4}(20 \mathrm{~cm})$ & 38,35 a & 58,95 & 74,05 & 84,06 & 2,09 & 4,98 & 6,06 & 6,25 & 4,26 & 179,39 \\
\hline
\end{tabular}

Keterangan : Angka pada kolom atau baris yang diikuti oleh huruf yang sama tidak berbeda nyata pada taraf 5\% menurut uji beda rataan DMRT (Duncan Multiple Range Test)

\section{SIMPULAN}

Varietaspadi gogo (Oriza sativa L.) menunjukkan perbedaan pertumbuhan dan produksi terhadap pertumbuhan dan produksi seperti tinggi tanaman tertinggi pada $4,6,8$ dan 10 MST, dimana varietas Situ Bagendit merupakan varietas yang tertinggi diantara varietas lainnya, hal yang sama pada pengamatan jumlah anakan pada umur 4, 6, 8 dan 10 MST, jumlah anakan produktif ditemukan pada varietas Situ Bagendit, jumlah gabah per malai tertinggi terdapat pada varietas Batutegi. Hasil yang tertinggi pada lahan gambut diperoleh pada varietas Situ Bagendit diikuti oleh varietas Batutegi, varietas Situ Patenggang dan varietas Lokal (varietas Siliam).

Amelioran tanah mineral berpengaruh terhadap pertumbuhan dan produksi beberapa varietas padi gogo (Oriza sativa L.). Komponen pertumbuhan yang dipengaruhi ketebalan tanah mineral meliputi: tinggi tanaman pada umur 4 MST tertinggi dipengaruhi oleh pemberian tanah mineral $\mathrm{T}_{2}$ $(10 \mathrm{~cm})$.

\section{DAFTAR PUSTAKA}

Adiratma. 2005. Pertumbuhan dan produksi beberapa varietas padi gogo. Medan.

[BPS]. 2013. Produksi Tanaman Pangan, Angka Sementara Tahun 2013. Jakarta.

Balai Penelitian Tanaman Padi. 2005.Pusat Penelitian dan Pengembangan Tanaman Pangan, Badan Litbang Pertanian.

Balai Penelitian Tanaman Padi. 2007. Padi Gogo dan Pola Pengembangannya.Deptan.

Damanik, S. M. 2002. Beras di Asia, Kisah Kehidupan Tujuh Petani. Penerbit Universitas Sumatera Utara Press.

IRRI.1997. Rice Almanac second edition IRRI. Los Banos. Fhilipphines. 181p

Kamura, A. 1956. Studies on the effect of internal nitrogen concentration of rice plants on constitutional factors of yield. 
Crop Science Society of Japan 24: 177180.

Lapulisa, C dan J. Siddieq.1998. Krakteristik Lahan Gambut di Daerah Pesisir Barat Pulau Muna, Sulawesi Utara dan Klasifikasinya menurut Soil Taksonomi.Prossiding Seminar Nasional Gambut III.HGI.UNTAN, Pemda Kalimantan Barat.BPPT Pontianak.

Manurung, S. O. dan Ismunadji. 1988. Morfologi dan Fisiologi Padi. Dalam Padi buku 1.Badan Penelitian dan Pengembangan Tanaman Pangan. Bogor. 319 hal.

Neliyati, S. 2005. Panduan Pengelolaan Lahan Gambut untuk Pertanian Berkelanjutan. Proyek Climate Change, Forests and Peatlands in Indonesia. Wetlands International-Indonesia Programme dan Wildlife Habitat Canada. Bogor.

Nurhayati.2013. Pengaruh Pengunaan Ameliroan terhadap Efektifitas dan
Intensivitas Mikroba pada Tanah Gambut dengan Kedelai sebagai Tanaman Indikator. J. Floratek 6: 124139.

Priyastomo, V. 2006.Peningkatan Produksi Padi Gogo Melalui Pendekatan Model Pengelolaan Tanaman dan Sumberdaya Terpadu. Universitas Muhammadiyah. Malang.

Setiawati, D. 2011. Pemantapan Formulasi Amelioran Pada Tanah Gambut Untuk Meningkatkan Produksi Padi ( Oryza sativa L.).

Supriyo dan E. Maftua'ah. 2009. Teknologi rehabilitasi lahan gambut bongkar untuk budidaya padi. Jurnal Ilmu Tanah dan Lingkungan Vol. 9 No. 1: 58-67.

Zuraida. 2013. Penggunaan berbagai jenis bahan amelioran terhadap sifat kimia bahan tanah gambut hemik. J. Floratek 8: 101-109. 